\title{
THE ABILITY OF LEAVES AND RHIZOMES OF AQUATIC PLANTS TO ACCUMULATE MACRO- AND MICRONUTRIENTS
}

\author{
Agnieszka Edyta Parzych', Małgorzata Cymer², Jerzy Jonczak³, Sławomir Szymczyk ${ }^{2}$
}

1 Pomeranian University in Słupsk, Bohaterów Westerplatte 64, 76-200 Słupsk, Poland, e-mail: parzycha1@op.pl

2 Department of Land Reclamation and Environmental Development, University of Warmia and Mazury in Olsztyn, Plac Łódzki 2, 10-719 Olsztyn, Poland

3 Department of Geoecology and Geoinformation, Pomeranian University in Słupsk, Partyzantów St. 27, 76200 Słupsk, Poland

Received: 2015.03.25

Accepted: 2015.06 .02

Published: 2015.07.01

\begin{abstract}
The samples of macrophytes and bottom sediments originated from the littoral zone of the Słupia River were collected in summer 2013. The aim of this study was to compare the properties of the accumulation of leaves and rhizomes of Glyceria maxima, Phragmites australis, Typha latifolia and Phalaris arundinacea for macro- and micronutrients. The largest quantities of macroelements were found in the leaves of the examined species, and microelements dominated the rhizomes of most examined macrophytes except for Mn in P.australis and T.latifolia. The obtained results show that $\mathrm{N}$ and $\mathrm{K}$ dominated in the leaves of P.arundinacea, $\mathrm{P}$ and $\mathrm{Mg}$ in the leaves of P.australis, and $\mathrm{Ca}$ in the leaves of G.maxima. The largest quantities of N, P and K were cumulated in the rhizomes of P.arundinacea, while $\mathrm{Mg}$ and $\mathrm{Ca}$ in the rhizome of T.latifolia. The leaves of aquatic plants accumulated from $1354.9 \mathrm{mmol} \cdot \mathrm{kg}^{-1}$ (T.latifolia) to $1844.0 \mathrm{mmol}_{\mathrm{c}} \cdot \mathrm{kg}^{-1}$ (P.arundinacea), and rhizomes from $985.8 \mathrm{mmol}_{\mathrm{c}} \cdot \mathrm{kg}^{-1}($ G.maxima $)$ to $1335.2 \mathrm{mmol}_{\mathrm{c}} \mathrm{kg}^{-1}$ (P.arundinacea) of all the analyzed components. In these species of macrophytes lower accumulated value of the sum of macro- and microelements were found in the rhizomes. The share of nitrogen was $42.4-59.8 \%$ of this amount, phosphorus $4.3-8.6 \%$, potassium $22.8-35.1 \%$, calcium from $2,6 \%$ to $12.4 \%$, magnesium $3.0-7.5 \%$, and heavy metals were from $0.6 \%$ (G.maxima) to $1.2 \%$ (T.latifolia) in leaves and from $2.2 \%$ (T.latifolia) to $8.7 \%$ (G.maxima) in rhizomes.
\end{abstract}

Keywords: bottom sediments, Glyceria maxima, Phragmites australis, Phalaris arundinacea, Typha latifolia, accumulation of nutrients.

\section{INTRODUCTION}

Dynamic development of civilization and progressive urbanization lead to comprehensive pollution of the natural environment. Waters as well as plants and bottom sediments of many rivers were encumbered with various toxic compounds [Garbisu and Alkorta 2003]. Their sources originate as the consequences of industrial and agricultural activity along with natural processes. At present, the intensity of exploitation of catchments and the inflow of sewage connected therewith have substantial impact on the chemical composition of bottom sediments [Sala- ti, Moore 2009]. Most pollutants introduced to rivers are connected with transported suspended matter whose deposition leads to origination of bottom sediments [Caldwell et al. 2002], and at the same time to increase of the content of macro and microelements of bottom sediments which constitute an important element of the water environment. Most components accumulated in the bottom sediments are available for littoral plants which accumulate them it in their sprouts. The research studies done hitherto confirm that the water plants reflect very well the status of pollution of water reservoirs both with biogenic compounds and heavy metals [Cardwell et al. 
2002, Klumpp et al. 2002, Kohler and Schneider 2003, Baldantoni et al. 2004, Demirezen and Askoy 2004, Schneider and Melzer 2004, Aksoy et al. 2005, Letachowicz et al. 2006, Sasmaz et al. 2008, Baldantoni et al. 2009, Bonanno and Lo Giudice 2010, Bonanno 2011, Klink et al. 2013]. In this respect, an increase in certain nutrients and the presence of pollutants are known to have an effect on the distribution of aquatic macrophytes [Bernez et al. 2001, Samecka-Cymerman and Kempers 2002]. Intake and bioaccumulation of necessary constituents is an element of the natural cycle [Kabata-Pendias and Szteke 2005, Dummee et al. 2012]. Aquatic macrophytes can obtain nutrients from the sediment as well as directly from the water itself [Schulz et al. 2003, Thiébaut and Muller 2003]. Differences in the quantity of accumulated elements can be observed not only among the species but also depending on the part of the plant, vegetation season and availability of the components [Alberts and Camardese 1993, Zhang et al. 2009]. The lower of the organization of the plants, the weaker their physiological barriers are developed, and accumulation of metals is passive. Some plant species form certain physiological barriers limiting transfer of the tonic compounds from rhizomes to leaves [Hozhina et al. 2001, Parzych et al. 2015]. Heavy metals content in aquatic plants can exceed many times their content in the biotopes surrounding water due to their fibrous root system of large contact surface area [Alberts and Camardese 1993, Burke et al. 2000, Aksoy et al. 2005, Bragato et al. 2009], and the wide scope of variability is caused by biological and ecological character of particular species.
Plants also play an essential role in the proper functioning of aquatic ecosystems. Produce oxygen dissolved in water, are involved in the circulation of nutrients, is a place of refuge for many aquatic organisms are involved in the process of self-purification of water and stabilize bottom sediments. Controlling the chemical composition of coastal vegetation and bottom sediment allows primarily the identification of existing and potential risks arising from the toxic effects of pollution on the aquatic environment and human health.

The aim of this study was to compare the properties of the accumulation of leaves and rhizomes of Glyceria maxima (Hartm.) Holmb., Phragmites australis (Cav.) Trin. ex Steud., Typha latifolia $\mathrm{L}$. and Phalaris arundinacea $\mathrm{L}$. for macro- and micronutrients. The contents of elements in aquatic plants were analyzed considering each component separately and in an integrated way - by comparing the demand for nutrients. The study takes into account the effect of the bottom sediments to the tested macrophytes.

\section{MATERIAL AND METHODS}

\section{Sampling site locations}

The research was carried out in summer 2013 year within the area of 10 stations situated with the limits of the city of Stupsk $\left(54^{\circ} 28^{\prime} \mathrm{N}, 17^{\circ} 02^{\prime} \mathrm{E}\right)$ along the Stupia River. The Stupia River is situated in the central part of Pomerania (northern Poland), (Figure 1). It is a lowland watercourse of the length of $138.6 \mathrm{~km}$ and of the area of the catchment of $1620 \mathrm{~km}^{2}$. The Stupia River headwater is at the

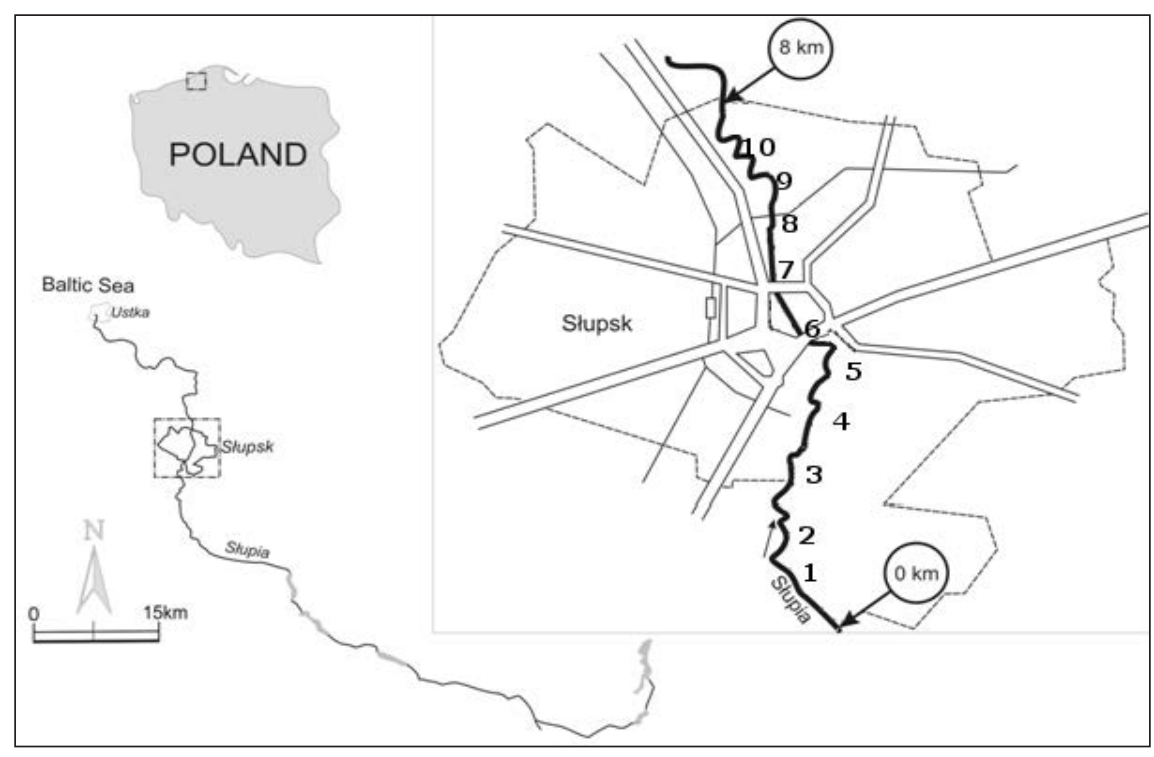

Figure 1. Distribution of the sampling points on the river Słupia 
Kashubian Lake District close to Sierakowska Huta at the height of $178 \mathrm{~m}$ a.s.1. The width of the water bed varies from $7 \mathrm{~m}$ in the upper part of the river to $40 \mathrm{~m}$ at its mouth, where the average flow is $15.5 \mathrm{~m}^{3} \cdot \mathrm{s}^{-1}$. The area of the City of Słupsk covers a $8 \mathrm{~km}$ stretch of the Słupia River, whose shores are covered with numerous macrophytes.

\section{Sample preparation and analytical methods}

The samples of bottom sediments and of leaves and rhizomes of Glyceria maxima, Phragmites australis, Typha latifolia and Phalaris arundinacea, originated from the littoral zone of the Słupia River (Figure 1). The bottom sediments were collected with the use of the Eckman sampler from the depth of $0-15 \mathrm{~cm}$. The samples were dried at the temperature $65^{\circ} \mathrm{C}$ (Drying Over), they were sieved through a sieve of $1 \mathrm{~mm}$ and grinded in a mortar. In bottom sediments acidity $(\mathrm{pH}$, $\mathrm{H}_{2} \mathrm{O}$ ) and organic matter content were indicated - by the method of heat loss in a muffle furnace at the temperature $550{ }^{\circ} \mathrm{C}$ for $4 \mathrm{~h}$. The samples of macrophytes within the area of each station were taken for the tests from several plants by preparation of mixed samples separately made of leaves and separately of rhizomes. The plant material was cleaned of mineral parts of the soil, flushed in the distilled water, dried to constant mass at the temperature of $65^{\circ} \mathrm{C}$ for $48 \mathrm{~h}$. Then, it was homogenized in a laboratory grinder (IKA A 11 basic, Germany). The total contents of nitrogen in bottom sediments and in plants was determined by Kiejdahl method (Büchi K-350, Destilation Unit, Switzerland), and the phosphorus by the molybdate method (spectrophotometer UV-VIS, Hitachi U-5100, Japan), after digested in the mixture of $98 \% \mathrm{H}_{2} \mathrm{SO}_{4}$ and $30 \% \mathrm{H}_{2} \mathrm{O}_{2}$. In order to determine the metallic elements, the bottom sediments and plant samples were digested wet in a closed system, in the mixture of $65 \% \mathrm{HNO}_{3}$ and $30 \%$ $\mathrm{H}_{2} \mathrm{O}_{2}$. The extracts were diluted to final volumes of $50 \mathrm{ml}$ with deionized water. The concentration of $\mathrm{Mg}, \mathrm{K}, \mathrm{Ca}, \mathrm{Zn}, \mathrm{Fe}, \mathrm{Mn}, \mathrm{Ni}$ and $\mathrm{Cu}$ in plants determined by atomic absorption spectrometry (AAS), (Aanalyst 300, Perkin Elmer, USA). The analyses were performed in the oxy-acetylene flame. The tests were carried out following the original standards (Merck KGaA, 1 g/1000 mL).

\section{Elaboration of results}

The distribution of the content of the analyzed elements was tested by the Shapiro-Wilk test. Due to the lack of normal distribution of data, nonparametric test was used. The significance of the differences in the macro- and microelements in the leaves and rhizomes of aquatic plants was verified by Mann Whitney U test. Moreover, the ratio was calculated rhizomes/leaves concentration (mean) ratios of research elements in G.maxima, P.australis, T.latifolia and P.arundinacea. Aquatic plant's demand for nutrients was described by the ANE (Accumulation Nutrient Elements) method according to Ostrowska [1987]. The sum of the components (Y) $\mathrm{mmol}_{\mathrm{c}} \cdot \mathrm{kg}^{-1}$ was calculated from the formula:

$$
Y=\sum_{i=1}^{i}(Z: z)
$$

where: $\mathrm{Z}$ - content of the element in $\mathrm{mg} \cdot \mathrm{kg}^{-1}$, $\mathrm{z}$ - atomic weight/ion valency.

After the calculation of $Y$, the percentage (X) of each element in the sum of:

$$
X=\frac{(Z: z) \cdot 100}{Y}
$$

was calculated. The study contained the effect of the sediments on the tested macrophytes (Table 1).

\section{RESULTS AND DISCUSSION}

The content of macroelements in sprouts of the plants reflects the level of their supply with nutrients. The largest quantities of $\mathrm{N}, \mathrm{P}, \mathrm{K}, \mathrm{Mg}$ and $\mathrm{Ca}$ were found in the leaves of the examined species of (Table 2, Table 3), which according to Sharma et al. [2006], is fully substantiated due to the process of photosynthesis which takes place therein. An exception was found only in the case of $\mathrm{Mg}$ (P.australis) and P (T.latifolia), whose quantity was little larger in the rhizomes than in the leaves (Table 3). The obtained results show that $\mathrm{N}$ and $\mathrm{K}$ dominated in the leaves of P.arundinacea $(\mathrm{N}=$ $\left.15320 \mathrm{mg} \cdot \mathrm{kg}^{-1}, \mathrm{~K}=19774 \mathrm{mg} \cdot \mathrm{kg}^{-1}\right), \mathrm{P}$ and $\mathrm{Mg}$ in the leaves of P.australis $\left(\mathrm{P}=3131 \mathrm{mg} \cdot \mathrm{kg}^{-1}, \mathrm{Mg}=\right.$ $\left.2508 \mathrm{mg} \cdot \mathrm{kg}^{-1}\right)$, while $\mathrm{Ca}$ dominate in the leaves of G.maxima $\left(\mathrm{Ca}=6864 \mathrm{mg} \cdot \mathrm{kg}^{-1}\right)$. The largest quantities of $\mathrm{N}, \mathrm{P}$ and $\mathrm{K}$ were cumulated in the rhizomes of P.arundinacea $\left(\mathrm{N}=9840 \mathrm{mg} \cdot \mathrm{kg}^{-1}\right.$, $\left.\mathrm{P}=2638 \mathrm{mg} \cdot \mathrm{kg}^{-1}, \mathrm{~K}=16443 \mathrm{mg} \cdot \mathrm{kg}^{-1}\right)$, and $\mathrm{Mg}$ and $\mathrm{Ca}$ in the rhizomes of T.latifolia $(\mathrm{Mg}=1990$ $\mathrm{mg} \cdot \mathrm{kg}^{-1}, \mathrm{Ca}=4258 \mathrm{mg} \cdot \mathrm{kg}^{-1}$ ) (Table 2). The highest values of N/P were found in the leaves of P.arundinacea (6.3), the lowest in the leaves of P.australis (3.7). The low levels of N/P ratio re- 
Table 1. Physical and chemical properties of bottom sediments

\begin{tabular}{|c|c|c|c|c|c|}
\hline \multicolumn{2}{|c|}{ Specification } & Average \pm SD & Median & Range & $\mathrm{CV}, \%$ \\
\hline \multicolumn{2}{|c|}{$\mathrm{pH}\left(\mathrm{H}_{2} \mathrm{O}\right)$} & $7.84 \pm 0.36$ & 7.95 & $7.00-8.19$ & 4.6 \\
\hline \multicolumn{2}{|c|}{ Organic matter, \% } & $2.14 \pm 2.51$ & 0.91 & $0.56-7.94$ & 117.0 \\
\hline $\mathrm{N}$ & \multirow{10}{*}{$\mathrm{mg} \cdot \mathrm{kg}^{-1}$} & $969.5 \pm 558.1$ & 665.0 & $560.0-2030.0$ & 57.5 \\
\hline$P$ & & $609.9 \pm 241.2$ & 514.8 & $396.2-1197.7$ & 39.5 \\
\hline $\mathrm{K}$ & & $506.7 \pm 191.7$ & 448.1 & $296.3-852.7$ & 37.8 \\
\hline $\mathrm{Ca}$ & & $2268.8 \pm 1471.5$ & 1677.7 & $848.3-5836.7$ & 64.9 \\
\hline $\mathrm{Mg}$ & & $842.9 \pm 309.7$ & 767.5 & $316.3-1328.7$ & 36.7 \\
\hline $\mathrm{Zn}$ & & $34.1 \pm 28.0$ & 22.8 & $12.4-104.7$ & 82.2 \\
\hline $\mathrm{Mn}$ & & $152.1 \pm 111.5$ & 119.0 & $58.1-376.7$ & 73.3 \\
\hline $\mathrm{Fe}$ & & $9293.5 \pm 4203.6$ & 7935.0 & $4008.0-15503.3$ & 45.2 \\
\hline $\mathrm{Cu}$ & & $8.4 \pm 4.4$ & 7.5 & $2.6-15.1$ & 52.8 \\
\hline $\mathrm{Ni}$ & & $11.9 \pm 2.8$ & 11.7 & $8.5-16.8$ & 23.5 \\
\hline
\end{tabular}

$\mathrm{SD}$ - standard deviation, $\mathrm{CV}$ - coefficient of variation.

sult from a small nitrogen content in the leaves of the examined aquatic plants as the effect of intensive growth in the summer season. According to Zhiguo et al. [2007] the most effective growth of plants takes place at the $\mathrm{N} / \mathrm{P}=9.5$, and according to Güsewell [2004] for most species the N/P ratio takes the levels $10-20$. The differences in the number of accumulated nutrients results from a physiological need and difference in species. Similar relations in the content of microelements in the leaves and rhizomes of aquatic plants were also presented in the studies of Vardanyan and Ingole [2006], Baldontini et al. [2009], as well as Klink et al. [2013].

The largest mean quantities of $\mathrm{Zn}$ and $\mathrm{Ni}$ were found in the leaves of P.australis $(\mathrm{Zn}=50.1$ $\left.\mathrm{mg} \mathrm{kg}^{-1}, \mathrm{Ni}=22.9 \mathrm{mg} \cdot \mathrm{kg}^{-1}\right), \mathrm{Mn}$ in T.latifolia $\left(\mathrm{Mn}=721.0 \mathrm{mg} \cdot \mathrm{kg}^{-1}\right), \mathrm{Fe}$ in P.arundinacea $(\mathrm{Fe}$ $\left.=261.3 \mathrm{mg} \cdot \mathrm{kg}^{-1}\right)$, and $\mathrm{Cu}$ in $\mathrm{w}$ G. maxima $(\mathrm{Cu}$ $\left.=10.2 \mathrm{mg} \cdot \mathrm{kg}^{-1}\right)$ (Table 2). The largest quantity of $\mathrm{Zn}, \mathrm{Mn}$ and $\mathrm{Ni}$ was found in the rhizomes of P.arundinacea $\left(\mathrm{Zn}=92.2 \mathrm{mg} \cdot \mathrm{kg}^{-1}, \mathrm{Mn}=1564.5\right.$ $\left.\mathrm{mg} \cdot \mathrm{kg}^{-1}, \mathrm{Ni}=36.9 \mathrm{mg} \cdot \mathrm{kg}^{-1}\right)$, and $\mathrm{Fe}$ as well as $\mathrm{Cu}$ in the rhizomes of $\mathrm{G}$. maxima $(\mathrm{Fe}=4259.9$ $\left.\mathrm{mg} \cdot \mathrm{kg}^{-1}, \mathrm{Cu}=21.1 \mathrm{mg} \cdot \mathrm{kg}^{-1}\right)$. The heavy metal content in the leaves of the examined aquatic plants was within the limits of permissible levels $\left(\mathrm{Zn}=70 \mathrm{mg} \cdot \mathrm{kg}^{-1}, \mathrm{Cu}=30 \mathrm{mg} \cdot \mathrm{kg}^{-1}\right)$ or exceeded them depending on a species and element $(\mathrm{Mn}$ $>500 \mathrm{mg} \cdot \mathrm{kg}^{-1}, \mathrm{Fe}>250 \mathrm{mg} \cdot \mathrm{kg}^{-1}, \mathrm{Ni}>5 \mathrm{mg} \cdot \mathrm{kg}^{-1}$ ), [Kabata-Pednias and Pendias 1999]. The increased content of Mn in sprouts of T.latifolia and P.arundinacea, in relation to physiological demand, may be species characteristic and may indicate a positive impact of these macrophytes on purification of waters and bottom sediments of manganese compounds. The research studies done by Teuchies et al. [2013], Klink et al. [2013], Letachowicz et al. [2006] and Demerizen and Aksoy [2004] confirm strong cumulative properties of leaves of T.latifolia in relation to manganese. The reaction of bottom sediments had a positive impact on bioavailability of $\mathrm{Mn}$ (Table 1). Manganese is characterized by an increased solubility not only in the acid biotope $(\mathrm{pH}=6)$, but also in alkaline one $(\mathrm{pH} 8),[\mathrm{Al}-$ loway 1995]. A little higher Fe content $(>250$ $\mathrm{mg} \cdot \mathrm{kg}^{-1}$ ) was found only in the case of the leaves of P.arundinacea, Table 2, which can be an effect of increased demand for that element in the summer time. The bottom sediments of the Słupia River, in which substantially increased Ni content was found (Table 1), [Parzych, et al. 2015]. Strong cumulative properties of some macrophytes in relation to Ni were confirmed by the studies of Salt and Kramer [2000] as well as Mays and Edwards [2001]. Nickel is easily accumulated by the plants and transported to their aboveground parts, and when in excess, it is accumulated in the roots [Kabata-Pendias and Pendias 1999].

Microelements dominated the rhizomes of most examined macrophytes except for $\mathrm{Mn}$ in P.australis and T.latifolia (Table 3). The level of rhizomes/leaves ratio (Fe) for G.maxima is worth mentioning. It confirms the retention of large quantities of iron in rhizomes in relation to leaves, which indicates the existence of a protective barrier limiting transfer of $\mathrm{Fe}$ to leaves [Hozhina et al. 2001, Parzych et al. 2015]. In 
Table 2. Average and $( \pm)$ standard deviation of elements content in aquatic plants

\begin{tabular}{|c|c|c|c|c|}
\hline \multirow{2}{*}{$\begin{array}{l}\text { Element } \\
\mathrm{mg} \cdot \mathrm{kg}^{-1}\end{array}$} & $\begin{array}{l}\text { Glyceria maxima, } \\
n=30\end{array}$ & $\begin{array}{l}\begin{array}{l}\text { Phragmites australis, } \\
\mathrm{n}=24\end{array} \\
\end{array}$ & $\begin{array}{c}\text { Typha latifolia, } \\
n=15\end{array}$ & $\begin{array}{l}\text { Phalaris arundinacea, } \\
\mathrm{n}=21\end{array}$ \\
\hline & \multicolumn{4}{|c|}{ Leaves } \\
\hline $\mathrm{N}$ & $10770 \pm 2739$ & $11424 \pm 2644$ & $8253 \pm 1041$ & $15320 \pm 3001$ \\
\hline$P$ & $2576 \pm 433$ & $3131 \pm 1137$ & $2200 \pm 609$ & $2419 \pm 531$ \\
\hline K & $12723 \pm 6015$ & $15293 \pm 3860$ & $17634 \pm 1829$ & $19774 \pm 4848$ \\
\hline $\mathrm{Ca}$ & $6864 \pm 3501$ & $2789 \pm 669$ & $6642 \pm 1420$ & $2414 \pm 706$ \\
\hline $\mathrm{Mg}$ & $1981 \pm 149$ & $2508 \pm 803$ & $1448 \pm 481$ & $2091 \pm 404$ \\
\hline $\mathrm{Zn}$ & $29.3 \pm 12.7$ & $50.1 \pm 24.1$ & $21.0 \pm 6$ & $29.1 \pm 6.4$ \\
\hline $\mathrm{Mn}$ & $261.7 \pm 179.1$ & $196.0 \pm 99$ & $721.0 \pm 453$ & $632.3 \pm 150.3$ \\
\hline $\mathrm{Fe}$ & $154.9 \pm 106.2$ & $150.2 \pm 32$ & $116.0 \pm 19$ & $261.3 \pm 98.2$ \\
\hline $\mathrm{Cu}$ & $10.2 \pm 2.3$ & $8.0 \pm 1.5$ & $7.2 \pm 0.3$ & $6.6 \pm 1.9$ \\
\hline \multirow[t]{2}{*}{$\mathrm{Ni}$} & $17.4 \pm 4.5$ & $22.9 \pm 10.8$ & $13.8 \pm 4.2$ & $17.1 \pm 12.1$ \\
\hline & \multicolumn{4}{|c|}{ Rhizomes } \\
\hline $\mathrm{N}$ & $6510 \pm 2227$ & $5391 \pm 2072$ & $6580 \pm 2381$ & $9840 \pm 3346$ \\
\hline$P$ & $2399.0 \pm 678$ & $1657 \pm 262$ & $1856 \pm 433$ & $2638 \pm 1027$ \\
\hline K & $9329 \pm 5146$ & $8292 \pm 3856$ & $15151 \pm 6468$ & $16443 \pm 5016$ \\
\hline $\mathrm{Ca}$ & $2952 \pm 2135$ & $1051 \pm 248$ & $4258 \pm 2354$ & $1338.4 \pm 556$ \\
\hline $\mathrm{Mg}$ & $1067 \pm 570$ & $570 \pm 78$ & $1990 \pm 752$ & $930.7 \pm 190$ \\
\hline $\mathrm{Zn}$ & $59.3 \pm 33.2$ & $68.0 \pm 66.6$ & $54.8 \pm 14.2$ & $92.2 \pm 28.5$ \\
\hline $\mathrm{Mn}$ & $441.2 \pm 383.1$ & $145.7 \pm 109$ & $320.1 \pm 209.1$ & $1564.5 \pm 1096$ \\
\hline $\mathrm{Fe}$ & $4259.9 \pm 5912.0$ & $719.8 \pm 716$ & $1018.6 \pm 1147.3$ & $1706.6 \pm 639$ \\
\hline $\mathrm{Cu}$ & $21.1 \pm 11.7$ & $13.0 \pm 14.8$ & $14.0 \pm 4.9$ & $11.1 \pm 3.7$ \\
\hline $\mathrm{Ni}$ & $24.9 \pm 4.6$ & $23.8 \pm 4.9$ & $27.3 \pm 7.5$ & $36.9 \pm 26.9$ \\
\hline
\end{tabular}

Table 3. Rhizomes/leaves concentration (mean) ratios of research elements in G.maxima,

P.australis, T.latifolia and P.arundinacea

\begin{tabular}{|c|c|c|c|c|}
\hline \multirow{2}{*}{ Element } & \multicolumn{4}{|c|}{ Rhizomes / Leaves } \\
\cline { 2 - 5 } & Glyceria maxima & Phragmites australis & Typha latifolia & Phalaris arundinacea \\
\hline $\mathrm{N}$ & 0.60 & 0.47 & 0.79 & 0.64 \\
$\mathrm{P}$ & 0.93 & 0.53 & 0.84 & 1.10 \\
$\mathrm{~K}$ & 0.73 & 0.54 & 0.86 & 0.83 \\
$\mathrm{Ca}$ & 0.43 & 0.38 & 0.64 & 0.55 \\
$\mathrm{Mg}$ & 0.54 & 0.23 & 1.37 & 0.44 \\
$\mathrm{Zn}$ & 2.02 & 1.36 & 2.45 & 3.17 \\
$\mathrm{Mn}$ & 1.68 & 0.74 & 0.44 & 2.47 \\
$\mathrm{Fe}$ & 21.50 & 4.79 & 8.77 & 6.53 \\
$\mathrm{Cu}$ & 2.06 & 1.68 & 1.01 & 1.68 \\
$\mathrm{Ni}$ & 1.43 & 1.04 & 1.96 & 2.16 \\
\hline
\end{tabular}

fact, the heavy metals may be mobilized in the bottom sediment of aquatic plants and to be taken up by plants or lost by leaching. In general, the concentration of heavy metals were relatively lower in leaves than in rhizomes [Baldontini et al. 2009, Klink et al. 2013]. However, the bioavailability and accumulation of heavy metals by plants depends on various factors such as: heavy metals content in bottom sediments, their bioavailability for plants, plant species, climatic factors and others. Translocation of trace metals from sediment to aboveground plant tissues differs greatly between species [Deng et al. 2004; Fitzgerald et al. 2003]. 
Macro- and microelements accumulation in leaves and rhizomes of selected species of aquatic plants showed a trends of:

- Glyceria maxima:

$\mathrm{K}>\mathrm{N}>\mathrm{Ca}>\mathrm{P}>\mathrm{Mg}>\mathrm{Mn}>\mathrm{Fe}>\mathrm{Zn}>\mathrm{Ni}>\mathrm{Cu}$ in leaves $\mathrm{K}>\mathrm{N}>\mathrm{Fe}>\mathrm{Ca}>\mathrm{P}>\mathrm{Mg}>\mathrm{Mn}>\mathrm{Zn}>\mathrm{Ni}>\mathrm{Cu}$ in rhizomes

- Phragmites australis:

$\mathrm{K}>\mathrm{N}>\mathrm{P}>\mathrm{Ca}>\mathrm{Mg}>\mathrm{Mn}>\mathrm{Fe}>\mathrm{Zn}>\mathrm{Ni}>\mathrm{Cu}$ in leaves $\mathrm{K}>\mathrm{N}>\mathrm{P}>\mathrm{Ca}>\mathrm{Fe}>\mathrm{Mg}>\mathrm{Mn}>\mathrm{Zn}>\mathrm{Ni}>\mathrm{Cu}$ in rhizomes

- Typha latifolia:

$\mathrm{K}>\mathrm{N}>\mathrm{Ca}>\mathrm{P}>\mathrm{Mg}>\mathrm{Mn}>\mathrm{Fe}>\mathrm{Zn}>\mathrm{Ni}>\mathrm{Cu}$ in leaves $\mathrm{K}>\mathrm{N}>\mathrm{Ca}>\mathrm{Mg}>\mathrm{P}>\mathrm{Fe}>\mathrm{Mn}>\mathrm{Zn}>\mathrm{Ni}>\mathrm{Cu}$ in rhizomes

- Phalaris arundinacea:

$\mathrm{K}>\mathrm{N}>\mathrm{P}>\mathrm{Ca}>\mathrm{Mg}>\mathrm{Mn}>\mathrm{Fe}>\mathrm{Zn}>\mathrm{Ni}>\mathrm{Cu}$ in leaves $\mathrm{K}>\mathrm{N}>\mathrm{P}>\mathrm{Fe}>\mathrm{Mn}>\mathrm{Ca}>\mathrm{Mg}>\mathrm{Zn}>\mathrm{Ni}>\mathrm{Cu}$ in rhizomes

Some of them are supported by the literature [Bonanno and Lo Giudice 2010]. The sum of the components reflects the whole so-called nutritional factor. The leaves of aquatic plants accumulated from $1354.9 \mathrm{mmol} \cdot \mathrm{kg}^{-1}$ (T.latifolia) to $1844.0 \mathrm{mmol}_{\mathrm{c}} \cdot \mathrm{kg}^{-1}$ (P.arundinacea), and rhizomes from $985.8 \mathrm{mmol}_{\mathrm{c}} \cdot \mathrm{kg}^{-1} \mathrm{~W}$ (G.maxima) to $1335.2 \mathrm{mmol} \cdot \mathrm{kg}^{-1}$ (P.arundinacea) of all the analyzed components. In these species of macrophytes lower accumulated value of the sum of macro- and microelements were found in the rhizomes (Table 4). Macroelements from 54.7\% (T.latifolia) to $67.9 \%$ (P.australis) were collected in leaves, and from $32.1 \%$ (P.australis) to $45.3 \%$ (T.latifolia) in rhizomes. Microele- ments characterized by a different distribution, from $8.9 \%$ (G.maxima) to $38.4 \%$ (T.latifolia) were accumulated in leaves, and from $61.6 \%$ (T.latifolia) to $91.1 \%$ (G.maxima) in rhizomes. The share of nitrogen was $42.4-59.8 \%$ of this amount, phosphorus $4.3-8.6 \%$, potassium $22.8-35.1 \%$, calcium $2,6 \%$ do $12.4 \%$, magnesium 3.0-7.5\%, and trace elements were from $0.6 \%$ (G.maxima) to $1.2 \%$ (T.latifolia) in leaves and from $2.2 \%$ (T.latifolia) to $8.7 \%$ (G.maxima) in rhizomes. The similar relations between the measured amount of ingredients in various plant species were shown by Parzych and Sobisz [2012]. A large share of manganese and iron in all components measured in leaves and rhizomes iron evidence of their excessive withdrawal from the bottom sediments, and encouraged neutral and alkaline bottom sediments (Table 1).

The U Manna Whitney test indicated a series of statistically vital differences in cumulative properties of the examined aquatic plant species in relation to macro- and micronutrients (Table 5). The most frequent diversification related to $\mathrm{Mg}, \mathrm{Mn}$ and $\mathrm{N}$. The differences in accumulation of $\mathrm{P}$ in the leaves of Typha latifolia and Phragmites australis as well as $\mathrm{K}$ in rhizomes of Glyceria maxima and Phalaris arundinacea. Only in the case of $\mathrm{Ni}$, no statistically vital differences in accumulation were found in the leaves and in rhizomes of examined macrophytes.

Table 4. Average of elements accumulation* in aquatic plants

\begin{tabular}{|c|c|c|c|c|c|c|c|c|}
\hline \multirow{2}{*}{ Element } & \multicolumn{4}{|c|}{ Leaves } & \multicolumn{4}{c|}{ Rhizomes } \\
\cline { 2 - 9 } & $\begin{array}{c}\text { Glyceria } \\
\text { maxima }\end{array}$ & $\begin{array}{c}\text { Phragmites } \\
\text { australis }\end{array}$ & $\begin{array}{c}\text { Typha } \\
\text { latifolia }\end{array}$ & $\begin{array}{c}\text { Phalaris } \\
\text { arundinacea }\end{array}$ & $\begin{array}{c}\text { Glyceria } \\
\text { maxima }\end{array}$ & $\begin{array}{c}\text { Phragmites } \\
\text { australis }\end{array}$ & $\begin{array}{c}\text { Typha } \\
\text { latifolia }\end{array}$ & $\begin{array}{c}\text { Phalaris } \\
\text { arundinacea }\end{array}$ \\
\hline$\Sigma$ macro [mmol//kg]: & 1433 & 1483 & 1339 & 1827 & 900 & 701 & 1108 & 1274 \\
$\%$ N in $\Sigma$ & 53.7 & 55.0 & 44.0 & 59.8 & 51.7 & 55.0 & 42.4 & 55.2 \\
$\%$ P in $\Sigma$ & 5.8 & 6.8 & 5.3 & 4.3 & 8.6 & 7.6 & 5.4 & 6.7 \\
$\%$ K in $\Sigma$ & 22.8 & 26.4 & 33.8 & 27.8 & 26.6 & 30.3 & 35.1 & 32.5 \\
$\%$ Ca in $\Sigma$ & 11.9 & 4.7 & 12.4 & 3.3 & 8.2 & 3.7 & 9.6 & 2.6 \\
$\%$ Mg in $\Sigma$ & 5.8 & 7.1 & 4.5 & 4.8 & 4.9 & 3.4 & 7.5 & 3.0 \\
\hline$\Sigma$ micro [mmol $/ \mathrm{kg}]:$ & 8.4 & 7.6 & 15.9 & 17.0 & 85.8 & 17.0 & 25.5 & 61.2 \\
$\%$ Zn in $\Sigma$ & 5.3 & 10.3 & 2.0 & 2.4 & 1.1 & 5.9 & 3.2 & 2.4 \\
$\%$ Cu in $\Sigma$ & 1.9 & 1.6 & 0.8 & 0.6 & 0.4 & 1.2 & 0.9 & 0.3 \\
$\%$ Ni in $\Sigma$ & 3.5 & 5.2 & 1.5 & 1.8 & 05 & 2.3 & 1.8 & 0.9 \\
$\%$ Mn in $\Sigma$ & 56.5 & 47.4 & 82.4 & 67.6 & 9.4 & 15.3 & 22.7 & 46.6 \\
\hline Fe in $\Sigma$ & 32.8 & 35.5 & 13.3 & 27.6 & 88.6 & 75.3 & 71.4 & 49.8 \\
\hline macro + $\Sigma$ micro & 1441.4 & 1490.6 & 1354.9 & 1844.0 & 985.8 & 718.0 & 1133.5 & 1335.2 \\
\hline
\end{tabular}

* Expressed as a form of the amount of these components and their participation in the total. 
Table 5. Statistical significance of differences (U Manna-Whitney's test)

\begin{tabular}{|c|c|c|c|c|c|c|c|c|c|c|c|}
\hline \multicolumn{2}{|l|}{ in relation: } & $\mathrm{N}$ & $\mathrm{P}$ & $\mathrm{K}$ & $\mathrm{Ca}$ & $\mathrm{Mg}$ & $\mathrm{Zn}$ & $\mathrm{Mn}$ & $\mathrm{Fe}$ & $\mathrm{Cu}$ & $\mathrm{Ni}$ \\
\hline \multirow{2}{*}{ G. maxima - $P$. australis } & leaves & * & ns & ns & $* * *$ & ns & * & ns & ns & * & ns \\
\hline & rhizomes & ns & ns & ns & ** & ** & ns & ns & ns & ** & ns \\
\hline \multirow{2}{*}{ G. maxima - T. latifolia } & leaves & ns & ns & ns & ns & ns & ns & * & ns & ** & ns \\
\hline & rhizomes & ns & ns & ns & ns & ns & ns & ns & ns & ns & ns \\
\hline \multirow{2}{*}{ G. maxima - P. arundinacea } & leaves & $* *$ & ns & ns & $* * *$ & ns & ns & $* *$ & * & ** & ns \\
\hline & rhizomes & ns & ns & * & * & $\mathrm{ns}$ & ns & * & ns & * & ns \\
\hline \multirow{2}{*}{ P. australis - T. latifolia } & leaves & * & * & ns & * & * & $\star *$ & $* *$ & ns & $\mathrm{ns}$ & $\mathrm{ns}$ \\
\hline & rhizomes & ns & ns & ns & ns & ns & ns & ns & ns & ns & ns \\
\hline \multirow{2}{*}{ P. australis - P. arundinacea } & leaves & ns & ns & ns & $* *$ & ns & $*$ & $* * *$ & $*$ & ns & ns \\
\hline & rhizomes & $* *$ & ns & ns & ns & ** & ns & $* *$ & ns & ns & ns \\
\hline \multirow{2}{*}{ T. latifolia - $P$. arundinacea } & leaves & * & ns & ns & * & ns & ** & ** & ns & ns & ns \\
\hline & rhizomes & * & ns & ns & * & ns & ns & ns & ns & ns & ns \\
\hline
\end{tabular}

ns - no significance, $*$ significance level of $\mathrm{p}<0.05, * *$ significance level of $\mathrm{p}<0.01$,

$* * *$ significance level of $\mathrm{p}<0.001$.

\section{CONCLUSIONS}

The largest quantities of macroelements were found in the leaves of the examined species, and microelements dominated the rhizomes of most examined macrophytes except for $\mathrm{Mn}$ in P.australis and T.latifolia. The content of macro- and microelements in aquatic plants was varied, depending on the species, and part of the shoot. The largest amounts of macronutrients in the leaves, and the smallest in rhizomes of macrophytes with the exception of manganese in P. australis and T. latifolia. The largest average amount of zinc and nickel were found in the leaves of $P$. australis, manganese in T. Latifolia, iron in P. arundinacea, and copper in G. maxima. Most of Zn, Mn and Ni demonstrated in rhizomes of $P$. arundinacea, and $\mathrm{Fe}$ and $\mathrm{Cu}$ in rhizomes of $G$. maxima. Increased Mn content in shoots of T. latifolia and P. arundinacea in relation this physiological needs refers to the beneficial effects of these species in the water treatment and sludge from the bottom sediment of manganese compounds. In the case of G. maxima the existence of protective barriers restricting movement of $\mathrm{Fe}$ from rhizomes to the leaves were found.

The leaves of aquatic plants accumulated from $1354.9 \mathrm{mmol} \cdot \mathrm{kg}^{-1}$ to $1844.0 \mathrm{mmol}_{\mathrm{c}} \cdot \mathrm{kg}^{-1}$, and rhizomes from $985.8 \mathrm{mmol}_{\mathrm{c}} \cdot \mathrm{kg}^{-1} \mathrm{~W}$ to 1335.2 $\mathrm{mmol}_{\mathrm{c}} \cdot \mathrm{kg}^{-1}$ of all the analyzed components. Macroelements from $54.7 \%$ to $67.9 \%$ were collected in leaves, and from $32.1 \%$ to $45.3 \%$ in rhizomes studied of aquatic plants. Microelements characterized by a different distribution, from $8.9 \%$ to $38.4 \%$ were accumulated in leaves, and from $61.6 \%$ to $91.1 \%$ in rhizomes.

\section{REFERENCES}

1. Aksoy A., Demirezen D., Duman F. 2005. Bioaccumulation, detection and analyses of heavy metal pollution in Sultan marsh and its environment. Water Air Soil Poll. 164, 241-255.

2. Alberts P.H., Camardese M.B. 1993. Effects as acidification on metal accumulation by aquatic plants and invertebrates. 1. Constructed wetlands. Environ. Toxicology Chem. 12 (6), 959-967.

3. Alloway B. J., 1995. Soil processes and the behavior of metals. In: Alloway B.J. (ed.) Heavy metals in soils. $2^{\text {nd }}$ ed. Blackie, Glasgow, 7-28.

4. Baldantoni D., Alfani A., Di Tommasi P., Bartoli G., Virzo de Santo A. 2004. Assessment of macro and microelement accumulation capability of two aquatic plants. Environ. Pollut. 130, 149-156.

5. Baldantonid D., Ligrone R., Alfania A. 2009. Macroand trace-element concentration in leaves and roots of Phragmites australis in volcanic lake in Southern Italy. J. Geochem. Explor. 101, 166.

6. Bernez I., Daniel, H., Haury J. 2001. Effects of perturbations on the aquatic vegetation of regulated river. Bull. Fr. Pêche Pisc., 357-60, 169-189.

7. Bonanno, G., 2011. Trace element accumulation and distribution in the organs of Phragmites australis (common reed) and biomonitoring applications. Ecotox. Environ. Safe. 74, 1057-1064.

8. Bonanno, G., Lo Giudice, R., 2010. Heavy metal bioaccumulation by the organs of Phragmites australis (common reed) and their potential use as contamination indicators. Ecol. Indic. 10, 639-645.

9. Bragato, C., Schiavon, M., Polese, R., Ertani, A., Pittarello, M., Malagoli, M., 2009. Seasonal variations of $\mathrm{Cu} \mathrm{Zn}, \mathrm{Ni}$ and $\mathrm{Cr}$ concentration in Phragmites australis (Cav.) Trin ex Steudel in a constructed wetland of North Italy. Desalination 246, 35-44.

10. Burke D.J., Weis J.S., Weis P. 2000. Release of metals by the leaves of salt marsh grasses Spartina alterni- 
flora and Phragmites australis. Estuar. Coast. Shelf Sci. 51, 153-159.

11. Cardwell A.J., Hawker D.W., Greenway M. 2002. Metal accumulation in aquatic macrophytes from southeast Queensland, Australia. Chemosphere 48, 653-663.

12. Demirezen D., Aksoy A. 2004. Accumulation of heavy metals in Typha angustifolia (L.) and Potamogeton pectinatus (L.) living insulta Marsh (Kayseri, Turkey). Chemosphere, 56, 685-696.

13. Deng H., Ye Z.H., Wong M. H. 2004. Accumulation of lead, zinc, copper and cadmium by 12 wetland plant species thriving in metal-contaminated sites in China, Environ. Pollut. 132, 29-40.

14. Dummee V., Kruatrachue M., Trinachartvanit W., Tanhan P., Pokethitiyook P., Damrongphol P. 2012. Bioaccumulation of heavy metals in water, sediments, aquatic plant and histopathological effects on the golden apple snail in Beung Boraphet reservoir, Thailand. Ecotox. Environ. Safe. 86, 204-212.

15. Fitzgerald E.J, Caffrey J.M, Nesaratnam S.T., Mc Loughlin P. 2003. Copper and lead concentrations in salt marsh plants on the Suir estuary, Ireland. Environ. Pollut. 123, 67-74.

16. Garbisu C., Alkorta I. 2003. Basic concepts on heavy metal soil bioremediation. Eur. J. Min. Proc. Environ. Prot. 13, 58-66.

17. Güsewell S. 2004. N:P ratios In terrestrial plants: variation and functional significance. New Phytologist 164, 243-266.

18. Hozhina E.I., Khramov A.A., Gerasimov P.A., Kumarkov A.A., 2001. Uptake of heavy metals, arsenic, and antimony by aquatic plants in the vicinity of ore mining and processing industries. J. Geochem. Explor. 74, 153-162.

19. Kabata-Pendias A., Pendias H. 1999. Biogeochemistry of trace elements, Polish Scientific Publishing, Warszawa.

20. Kabata-Pendias A., Szteke B. 2005. Trace elements in soil-plant system. Inżynieria Ekologiczna 26, 28-29.

21. Klink A., Wisłocka M., Musiał M., Krawczyk J. 2013. Macro- and trace- elements accumulation in Typha angustifolia L. and Typha latifolia L. organs and their use in bioindycation. Pol. J. Environ. Stud. $22,1,183-190$.

22. Klumpp A., Bauer K., Franz-Gerstein C., de Menezes M. 2002. Variation of nutrient and metal concentrations in aquatic macrophytes along the Rio Cachoeira in Bahia (Brazil). Environ. Intern., 28, 165-171.

23. Kohler A., Schneider S. 2003. Macrophytes as bioindicators. Arch. Hydrobiol., Suppl., 147, 17-31.

24. Letachowicz B., Krawczyk J., Klink A. 2006. Accumulation of heavy metals in organs of Typha lalifolia L., Pol. J. Environ. Stud. 15 (2a), 407-409.

25. Mays P.A., Edwards G.S. 2001. Comparison of heavy metal accumulation in a natural wetland and constructed wetlands receiving acid mine drainage, Ecol. Eng. 16, 487-500.
26. Ostrowska A., 1987. Application of ANE value and shares of individual elements in this value for determining the difference between various plant species. Genetic aspects of plant mineral nutrition, 27 43, Martinus Nijhoff Pub. (Plant and Soil).

27. Parzych A., Sobisz Z., Cymer M., 2015. Preliminary research of heavy metals content by aquatic macrophytes taken from surface water (northern Poland). Desalination and Water Treatment, in press.

28. Parzych A., Sobisz Z., 2012: The macro- and microelemental content of Pinus sylvestris L. and Pinus nigra Arn. needles in Cladonio-Pinetum habitat of the Słowiński National Park, Forest Research Papers 73 (4), 295-303.

29. Salati S., Moore F., 2009. Assessment of heavy metal concentration in the Khoshk River water and sediment, Shiraz, Southwest Iran, Environ. Monit. Assess. 164, 677-689.

30. Salt D.E., Kramer U., 2000. Mechanisms of metal hyperaccumulation in plants, phytoremediation of toxic metals: Using plants to clean up the environment, In: I. Raskin and B.D. Ensley (Eds.), Wiley and Sons, 231-246.

31. Samecka-Cymerman A., Kempers A.J. 2002. Aquatic macrophytes as biomonitors of pollution by textile industry. Bull. Envi. Cont. Tox., 69, 82-96.

32. Sasmaz A., Obek E., Hasar H. 2008. The accumulation of heavy metals in Typha latifolia L. grown in a stream carrying secondary effluent, Ecol. Eng. 33, (3-4), 78.

33. Schneider S., Melzer A. 2004. Sediment and water nutrient characteristics in patches submerged macrophytes in running waters. Hydrobiologia, 527, 195-207.

34. Schulz M., Kozerski H.P., Pluntke T., Rinke K. 2003. The influence of macrophyte on sedimentation and nutrient retention in the lower River Spree (Germany). Water Res., 37, 569-578.

35. Sharma P., Asaeda T., Manatunge J., Fijino T. 2006. Nutrient cycling in a natural stand of Typha angustifolia J. Freshwater Ecol. 21, 431-438.

36. Teuchies J., Jacobs S., Oosterlee L., Bervoets L., Meire P. 2013. Role of plants in metal cycling in a tidal wetland: Implications for phytoremediation, Sci. Tot. Environ. 445-446, 146-154.

37. Thiébaut G., Muller S. 2003. Linking phosphorus pools of water, sediment and macrophytes in running waters. Ann. Limnol - Int. J. Lim., 39, 307-316.

38. Vardanyan L.G., Ingole B.S., 2006. Studies of heavy metal accumulation in aquatic macrophytes from Sevan (Armenia) and Carambolim (India) lake systems, Environ. Internat. 32, 208-218.

39. Zhang M., Cui L., Sheng L., Wang Y., 2009. Distribution and enrichment of heavy metals among sediments, water body and plants in Hengshuihu Wetland of Northern China. Ecol. Eng. 35, 563-569.

40. Zhiguo X., Baixing Y., He Y., Changchum S. 2007. Nutrient limitation and wetland botanical diversity in northeast China: can fertilization influence on species richness? Soil Science 172, 1, 86-93. 